\title{
SUB-RECENT MARINE OSTRACODA (PONTOCYPRIDIDAE AND BAIRDIIDAE) FROM THE SOUTHERN BRAZILIAN CONTINENTAL SHELF
}

\author{
MARIA INÊS FEIJÓ RAMOS \\ CPPG, MPEG, Av. Perimetral, 1901, Cx. P. 399, 66077-530, Belém, PA, Brazil.mramos@museu-goeldi.br \\ ROBIN C. WHATLEY \\ Micropalaeontology Unit, Department of Geology, University of Wales, Aberystwyth, SY23 3DB, UK. riw@aber.ac.uk \\ JOÃO CARLOS COIMBRA \\ Departamento de Paleontologia e Estratigrafia, UFRGS, Cx. P. 15001, 91501-970, Porto Alegre, RS, Brazil. joao.coimbra@ufrgs.br
}

\begin{abstract}
This work is part of a long-term project that attempts to describe the Ostracoda present in the southern Brazilian shelf between Rio de Janeiro and Rio Grande do Sul states (almost 2,050 km in length), and to assess the zoogeographical significance of a total 102 benthic species. In this paper the families Pontocyprididae and Bairdiidae have been identified with the description of five new taxa: Argilloecia inflata, A. subacuta, Pontocypris? punctatus, Bairdoppilata sudbrasiliensis, and Neonesidea? rotunda. Argiloecia parameridionalis Whatley et al., is here recorded farther north than previous records.
\end{abstract}

Key words: Sub-Recent, marine, ostracods, Pontocyprididae, Bairdiidae, south Brazil.

\begin{abstract}
RESUMO - O presente trabalho é parte de um projeto maior que pretende descrever os Ostracoda presentes na plataforma continental sul-brasileira, entre os estados do Rio de Janeiro e Rio Grande do Sul (aproximadamente $2.050 \mathrm{~km}$ de extensão), bem como interpretar o significado zoogeográfico de um total de 102 espécies. As famílias Pontocyprididae e Bairdiidae são representadas por quatro e duas espécies, respectivamente, sendo cinco novas: Argilloecia inflata, A. subacuta, Pontocypris? punctatus, Bairdoppilata sudbrasiliensis e Neonesidea? rotunda. Argilloecia parameridionalis Whatley et al., tem sua distribuição extendida para o norte.
\end{abstract}

Palavras-chave: Sub-recente, marinho, ostracodes, Pontocyprididae, Bairdiidae, sul do Brasil.

\section{INTRODUCTION}

This study is part of the doctoral thesis by Ramos (1998), who studied the taxonomy and zoogeography of benthic Recent marine ostracods from the southern Brazilian continental shelf of sub-orders Podocopina, Platycopina and Cladocopina. The total ostracod fauna is represented by 17 families, 47 genera and 102 species. Forty-two species also occur as fossil, three ranging back to the Oligocene, sixteen to the Miocene, and nineteen to the Quaternary. A number of these species (62\%) are restricted to the southern Brazilian coast. Also, $38 \%$ of species extend southwards to the Uruguayan and Argentinean coasts.

Although the species of the families Pontocyprididae and Bairdiidae considered herein comprise only a small part of the overall studied ostracode fauna, they are important, since most are new and their register will contribute to the future zoogeographical studies. Subsequent taxonomical papers will deal with the Platycopina and the various families of Cytheracea.

\section{Previous studies}

The study of the Recent marine ostracods from the southern Brazilian shelf began with Hartmann $(1955,1956)$, where a few new species of the families Cytheridae, Cytheruridae, Loxoconchidae and Paradoxostomatidae were recorded from the northern inner shelf off São Paulo State. This was followed by a series of papers dealing with the generic and specific descriptions of a number of marine taxa from south Brazil (Coimbra \& Ornellas, 1987; Purper \& Ornellas, 1989; Coimbra et al., 1994, 1995; Carmo \& Sanguinetti, 1995, 1999; Machado \& Drozinski , 2002; Coimbra \& Bergue, 2001, 2003; Aiello et al. in press). Publications at higher taxonomic level can be found in Ramos $(1994,1996)$ that studied the subfamily Coquimbinae along the Brazilian shelf, Ramos et al. (1999) with the study of the family Cytheruridae from Rio de Janeiro coast, both with descriptions of new species, and Whatley et al. (1998a) and platycopid ostracods from part of the Southern Brazilian coast. 
Four studies with emphasis in zoogeography are very important for the knowledge of the ostracod geographical distribution patterns in the study area. On the basis of the distribution of the subfamily Orionininae and of the genus Callistocythere, Coimbra \& Ornellas (1989) and Coimbra et al. (1995) reckon the existence of three assemblages in the Brazilian continental shelf: Northern-Eastern, Southern and Transitional assemblages. In a preliminarily study based on the distribution of ostracod assemblages, Whatley et al. (1998b) proposed five zoogeographical provinces for the area localized between Rio de Janeiro $\left(22^{\circ} \mathrm{S}\right.$, Brazil) and Tierra del Fuego $\left(55^{\circ} \mathrm{S}\right.$, Argentina). Finally, Wood et al. (1999) described key patterns in the distribution of marine Ostracoda genera since Oligocene to Recent in the SW Atlantic and adjacent areas.

\section{STUDY AREA}

The study area comprises the southern Brazilian continental shelf from Rio de Janeiro to Rio Grande do Sul states, between latitudes $21^{\circ} \mathrm{S}$ and $35^{\circ} \mathrm{S}$ and longitudes $40^{\circ} \mathrm{W}$ and $57^{\circ} \mathrm{W}$, covering almost $2,050 \mathrm{~km}$ in length. It is located in the South Region (subdivision of Chaves, 1983), and its maximum width is around Santos city (SP), reaching $230 \mathrm{~km}$, while the minimum is off Cabo Frio town (RJ), at only $80 \mathrm{~km}$. The mean width is about $130 \mathrm{~km}$ (Figure 1).

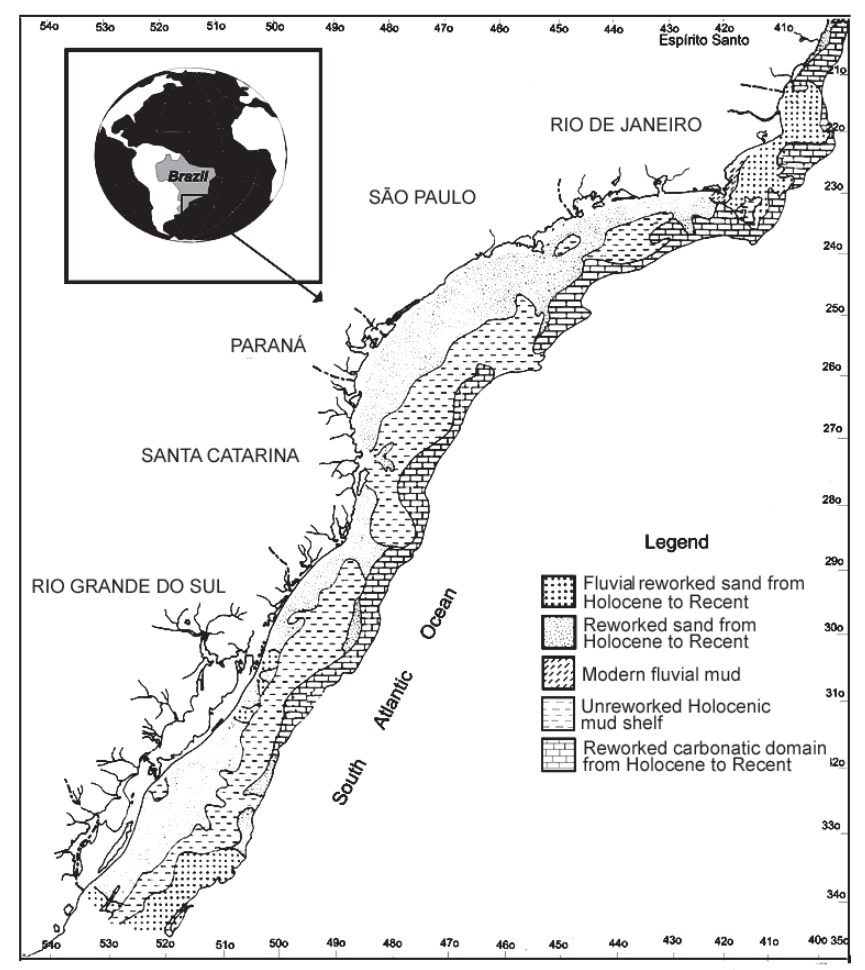

Figure 1. Location of the study area and distribution of bottom sediment types (modified from Kowsmann \& Costa, 1979).

\section{Sedimentology}

The distribution of the sediments in this area comprises a mixture of Recent and relict deposits, the product of modern hydrodynamical processes and glacio-eustatic variations during the Quaternary, especially the influence of the Wisconsinian Regression and Holocene Transgression.
According to Koswmann \& Costa (1979) the area possesses two main domains: terrigenous and carbonate. The terrigenous domain comprises a mixture of muddy and sandy sediments, predominating between Vitória City $\left(20^{\circ} 19^{\prime} \mathrm{S}\right)$ and the town of Cabo Frio (22 $2^{\circ} 3^{\prime} S$ ) on the inner and middle shelf respectively, and from Cabo Frio to the town of Chuí (33⒋ where they predominate on the outer shelf. The carbonate sediments between Vitória City and Cabo Frio comprise more than $95 \%$ on the outer shelf, while from Cabo Frio to the town of Mostardas (31 $\left.06^{\prime} \mathrm{S}\right)$, they rarely exceed 50-70\% (Figure 1). The carbonate sediments comprise algal reef sand, benthonic foraminifers and a mixture of molluscs with bryozoans. The poor preservation of the biotic components of the carbonate facies is due to high levels of reworking and high environmental energy (Koswmann \& Costa, 1979).

\section{Oceanography}

The oceanic water masses are the main factor influencing the geographical distribution of the ostracods, and their different temperatures and salinities are directly related to latitude and current systems. According to data from Boltovskoy (1970, 1976, 1979, 1981), Weber (1994), Martins (1984) and Godoi (1982), six types of water masses influence the southern Brazilian continental margin: Sub-Antarctic Water, South Atlantic Central Water, Antarctic Intermediate Water, Coastal Water, Tropical Water and Subtropical Water; characterised by typical temperature and salinity ranges.

The main currents influencing the southern Brazilian continental shelf are Brazil and Falklands currents. The Brazil

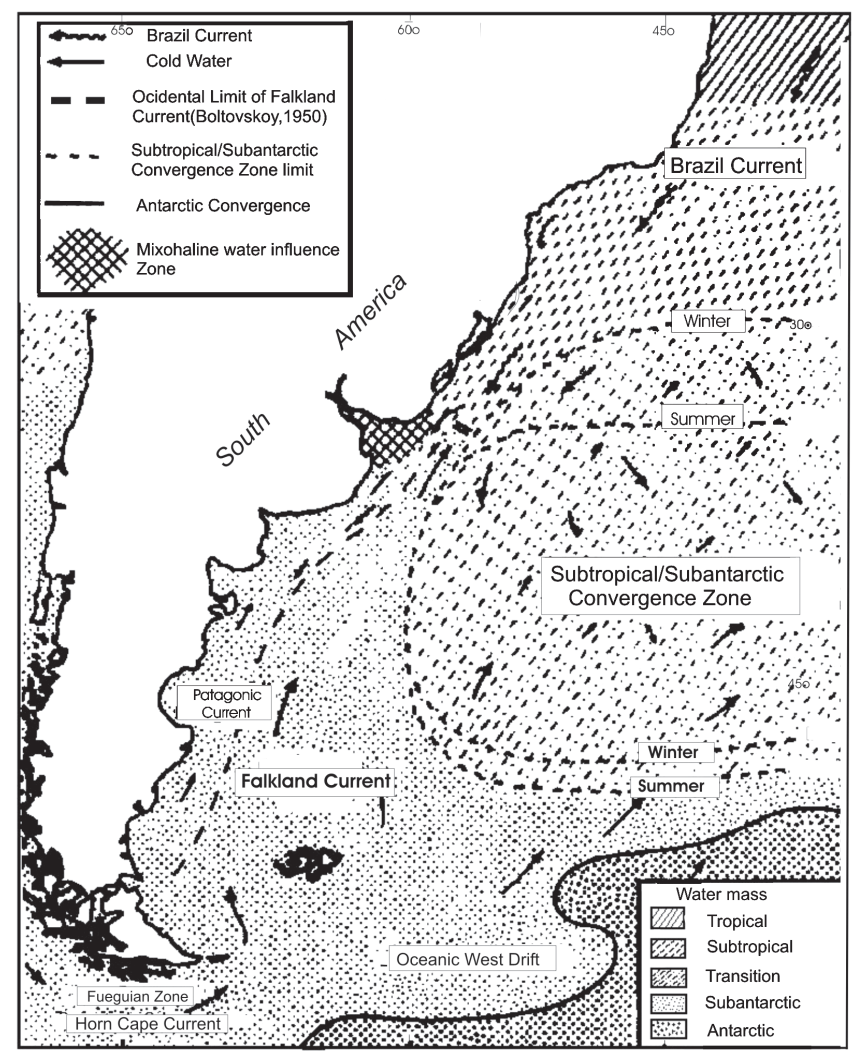

Figure 2. Oceanographical map of the South West Atlantic (modified from Boltovskoy, 1981). 
Current is part of the South Equatorial Current and flows from $8^{\circ} \mathrm{S}$ to $38^{\circ} \mathrm{S}$ with waters of high temperature and salinity. In the summer, this current reaches $40^{\circ} \mathrm{S}$ with temperatures between $24^{\circ} \mathrm{C}$ and $27^{\circ} \mathrm{C}$ and salinities around $36 \%$ and $37 \%$. In the winter, the Brazil Current extends from $29^{\circ} \mathrm{S}$ to $39^{\circ} \mathrm{S}$, with temperature of $22^{\circ} \mathrm{C}$ and salinity of $36 \%$ to $36.5 \%$. The Falklands Current is part of the Sub-Antarctic Water and flows from the Falklands Islands and the Patagonian coast to latitude $35^{\circ} \mathrm{S}$, where it meets the Brazil Current. In the winter it extends as far north as $30^{\circ} \mathrm{S}$ (Tramandaí town) because of the discharge of the La Plata River. The temperatures change within this current according to the season, with averages of $4^{\circ} \mathrm{C}$ around the Falklands Islands $\left(\sim 52^{\circ} \mathrm{S}\right)$ and $20^{\circ} \mathrm{C}$ along the Rio Grande city $\left(\sim 32^{\circ} \mathrm{S}\right)$. At its most northern limit it flows northwards beneath the southward flowing Brazil Current. The northest influence of the Sub-Antarctic Water occurs at around $21^{\circ} \mathrm{S}$ (near Cape São Tomé) (Figure 2).

\section{MATERIAL AND METHODS}

The 500 samples, on which this study is based, were collected by Phillips and Van Veen grabs during a series of cruises. The samples are from REMAC Project (Legs 1, 2 and 3), GEOMAR VI and from the NOc."El Austral"; only 207 samples yielded ostracods. The preparation of the samples was by standard methods. Specimens were illustrated using the "Cambridge Stereoscan 120" SEM from the Department of Geology, University of Wales, Aberystwyth, UK. The study of some species was facilitated by comparison with the lectotypes of the Brady (1880) collection. The following conventions are employed: B.M. (Department of Zoology) and with the Moguilevsky collection=AM, Toy collection=NT and Chadwick collection=JC (Department of Palaeontology) all housed in the Natural History Museum, London.

The type material is housed in the collections of the 'Museu de Paleontologia', Universidade Federal do Rio Grande do Sul, Section of Ostracoda (MP-O-1817 to MP-O-1837).

\section{SYSTEMATIC DESCRIPTIONS}

\author{
Suborder PODOCOPINA Sars, 1866 \\ Superfamily CYPRIDACEA Baird, 1845 \\ Family PONTOCYPRIDIDAE Müller,1894 \\ Genus Argilloecia Sars, 1866
}

\section{Argilloecia parameridionalis Whatley, Moguilevsky, Chadwick, Toy \& Ramos, 1998a.}

(Figure 3: 1, 2)

Argilloecia parameridionalis Whatley et al., 1998a:91, pl. 1:1-5. Argilloecia parameridionalis Drozinski et al., 2003, tab. 2, fig. 4e.

Emended diagnosis. A species of Argilloecia closely resembling A. meridionalis Brady, from which it is distinguished by its smaller size, more umbonate dorsal margin, and differences in the nature of the inner lamella and radial pore canals.
Carapace, elongate-subovate, narrowly rounded anteriorly, dorsally subumbonate. Anterior vestibulum almost residual. Figured Specimen. MP-O-1817, carapace.

Material. 262 adult valves, 96 carapaces and 8 juveniles. Locality and horizon. Southern Brazilian continental shelf, sample GVI-349 (31 $24,5^{\prime} \mathrm{S}, 50^{\circ} 41^{\prime} \mathrm{W}$, depth $\left.60 \mathrm{~m}\right)$. Recent.

Dimensions (mm). Homotype MP-O-1817: RV, length: 0.60; height: 0.24 ; LV, length: 0.60; height: 0.27. Homotype MP-O1818: RV, length: 0,58; height: 0.24; width: 0.22; LV, length: 0.56 ; height: 0.26 .

Remarks. The present specimens have the same characteristics of the type-material housed in the Natural History Museum, London. This species was originally described from Recent sediments from Argentina and southernmost Brazil by Whatley et al. (1998a). In the present study, its geographical distribution is expanded to $22^{\circ} 24.5^{\prime} \mathrm{S}$, with the most southerly occurrence being $52^{\circ} 13,5^{\prime} \mathrm{S}$. The diagnosis of this species is emended to complement that given by Whatley et al. (1998a).

Distribution. Argentinean and southern Brazilian continental shelves between $22^{\circ} 24.5^{\prime} \mathrm{S}$ and $52^{\circ} 13.5^{\prime} \mathrm{S}$. Depth range between $15 \mathrm{~m}$ and $155 \mathrm{~m}$, and occurring preferentially on sands. In the present study it occurs predominantly in sandy and muddy sediments.

\section{Argilloecia inflata sp. nov.}

(Figure 3: 4, 5, 7, 8)

Argilloecia sp. 2. Whatley et al., 1998a: 92, pl. 1:8-11.

Argilloecia sp. 1. Drozinski et al., 2003, tab. 2, fig. 4f.

Derivation of name. $L$. with reference to the inflated carapace of this species.

Diagnosis. Elongate subrectangular, rather thick-shelled. Smooth, except for weak ribs antero-dorsally. Inflated, but parallel-sided in dorsal view. Inequivalve, with RV much larger and strongly overlapping LV, especially dorsally.

Holotype. MP-O-1819, carapace.

Paratypes. MP-O-1820, carapace; MP-O-1821, carapace.

Material. 43 adult valves and 14 carapaces.

Type locality and horizon. Southern Brazilian continental shelf,

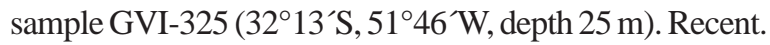

Description. Elongate subretangular in lateral view. Inflated, but parallel-sided in dorsal view. RV with rounded anterior margin and weak antero-dorsal projection; bluntly pointed posterior margin with long postero-dorsal slope and subventral apex; dorsal margin slightly convex, almost straight medianly and without posterior cardinal angle; ventral margin sinuous, slightly concave orally and upturned posteriorly. LV with anterior margin irregulary and rather narrowly rounded and with weak antero-dorsal projection; posterior margin bluntly pointed and with apex slightly less ventral than RV; dorsal margin more convex than in the RV; ventral margin more strongly concave orally. Surface smooth with small antero-dorsal ribs. RV much larger than LV with strong overlap, especially dorsally. Internal characters as for genus.

Dimensions (mm). Holotype MP-O-1819: RV, length: 0.60; 
height: 0.30; LV, length: 0.58; height: 0.26. Paratype MP-O1820: RV, length: 0.60; height: 0.30; width: 0.28; LV, length: 0.60; height: 0.28. Paratype MP-O-1821: RV, length: 0.60; height: 0.30; width: 0.28; LV, length: 0.60; height: 0.28.

Remarks. This species is very similar to Argilloecia robusta Bonaduce et al., 1975, from the Quaternary of the Adriatic Sea. It differs mainly in its larger size, in the posterior area of LV being more rounded ventrally, dorsally more arched and the vestibulum of the LV being smaller anteriorly. The present specimens are identical to those found on the Argentinean continental shelf by Whatley et al. (1998a), and southernmost Brazil by Drozinski et al. (2003).

Distribution. Recent sediments from Argentinean continental shelf at $52^{\circ} 15.8^{\prime} \mathrm{S}$ (Whatley et al., 1998a) and the Brazilian continental shelf between $22^{\circ} 42.5^{\prime} \mathrm{S}$ and $33^{\circ} 50.5^{\prime} \mathrm{S}$. Depth ranges from $42 \mathrm{~m}$ to $136 \mathrm{~m}$, in sandy and muddy sediments.

\section{Argilloecia subacuta sp. nov. \\ (Figure 3: 3, 6, 9, 10)}

Derivation of name. $L$. with reference to the acute posterior margin. Diagnosis. Elongate subrectangular. Anterior rather narrowly; posterior with acutely subventral apex. LV with long, straight antero-dorsal slope towards anterior margin; RV with this slope weakly convex.

Holotype. MP-O-1822, carapace.

Paratype. MP-O-1823, carapace.

Material. 70 adult valves and 31 juveniles.

Type locality and horizon. Southern Brazilian continental shelf, sample GVI-329 (32 $36^{\prime} \mathrm{S}, 5^{\circ} 05^{\prime} \mathrm{W}$, depth $\left.62 \mathrm{~m}\right)$. Recent.

Description. Elongate subrectangular in lateral view. Rather flat-sided in dorsal view, with posterior only a little more acuminate than anterior. RV with the anterior margin rather narrowly rounded and rounded antero-cardinal angle; LV with a marked antero-cardinal angle. Posterior margin acutely pointed subventrally. Dorsal margin of LV with long, straight antero-dorsal slope towards anterior margin; RV with this slope weakly convex. Ventral margin with broad, shallow median concavity. Greatest length below mid-height; greatest height $2 / 3$ of the distance from the anterior margin; greatest width equal between the cardinal angles. Surface almost smooth, slightly punctate anteriorly. Inner lamella narrow with large vestibulum especially anteriorly.

Dimensions (mm). Holotype MP-O-1822: RV, length: 0.54, height: 0.22; LV, length: 0.50, height: 0.22. Paratype MP-O1823: RV, length: 0.56, height: 0.24; LV, length: 0.54, height: 0.24 , width: 0.20 .

Remarks. Argilloecia subacuta sp. nov. resembles Argilloecia sp. 5 Whatley \& Coles (1987) from the North Atlantic, but the latter differs in its more ventral posterior apex and in its concave antero-dorsal slope. The present species is also similar to Aglaia (?) pusilla Brady (1880) (Brady Collection, lectotype BM 81.5.2), but differs in being larger, in that the LV that is more pointed, the dorsum is more arched and the ventral margin more concave. Also, the RV of the latter species is more rounded postero-dorsally and more pointed medianly. It differs from Argilloecia eburnea Brady
(1880) (Brady Collection, lectotype B.M 80.38.9) in its smaller size and narrower anterior end.

Distribution. South Brazilian continental shelf between $32^{\circ} 57^{\prime}$ and $22^{\circ} 46^{\prime} \mathrm{S}$. Depth range from $25 \mathrm{~m}$ to $156 \mathrm{~m}$. It occurs on sandy and muddy substrates.

Genus Pontocypris Sars, 1866

Pontocypris? punctatus sp. nov.

(Figure 3: 11, 12, 15)

Derivation of name. $L$. with reference to its punctate ornament. Diagnosis. Carapace subtriangular elongate, with widely rounded anteriorly and very acuminate and convergent posteriorly. Surface finely punctate.

Holotype. MP-O-1824, carapace.

Paratypes. MP-O-1825, carapace; MP-O-1826, VE; MP-O1827, VD.

Material. 22 adult valves and 10 juveniles.

Type locality and horizon. Southern Brazilian continental shelf, sample Leg 2-3134 (28 23' S, 47³4`W, depth 153 m). Recent. Description. Very subtriangular elongate in lateral view and strongly convergent posteriorly. Anterior margin broadly rounded. Posterior margin very strongly pointed below midheight. Dorsal margin slightly arched in the LV and almost straight in the RV, very strongly sloping towards the posterior. Ventral margin strongly concave medianly. Surface finely punctate. Internal features as for genus.

Dimensions (mm). Holotype MP-O-1824: RV, length: 0.70; height: 0.30; LV, length: 0.72; height: 0.30. Paratype MP-O1825: RV, length: 0.72; height: 0.30; LV, length: 0.74; height: 0.30. Paratype MP-O-1826: LV, length: 0.72; height: 0.30 .

Remarks. Pontocypris? punctatus sp. nov. lacks the serrated postero-ventral margin of the RV, as described by Maddocks (1969, p.43) in her diagnosis of the genus. However, this species is considered as Pontocypris because of its internal characteristics and the design of the carapace. It is similar to Pontocypris? sp. 6 Maddocks, 1969, which also lacks the postero-ventral serrated margin. Pontocypris? punctatus sp. nov. differs from Pontocypris? sp. 6 Maddocks, 1969 by its more prominent antero-dorsal angle; the posterior of the LV is upturned and the dorsal margin is straighter.

Distribution. Southern Brazilian continental shelf between $32^{\circ} 57^{\prime} \mathrm{S}$ and $24^{\circ} 20.5^{\prime} \mathrm{S}$; depth range from $47 \mathrm{~m}$ to $153 \mathrm{~m}$. It occurs on muddy and sandy biodetritic sediments.

Superfamily BAIRDIACEA Sars, 1888 Family BAIRDIIDAE Sars, 1888

Subfamily BAIRDIINAE Sars, 1888

Genus Bairdoppilata Coryell, Sample \& Jennings, 1935

Bairdoppilata sudbrasiliensis sp. nov. (Figure 3: 13, 14, 16, 17)

Bairdoppilata sp. Drozinski et al., 2003, tab. 2, fig. 4m.

Derivation of name. With reference to the type locality. 

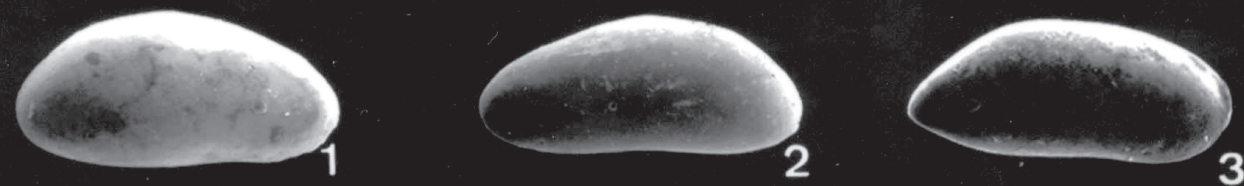

3
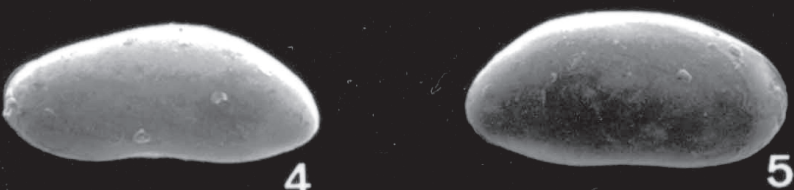

5

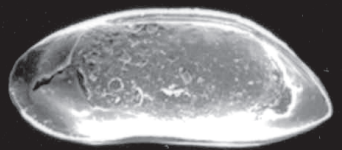

10

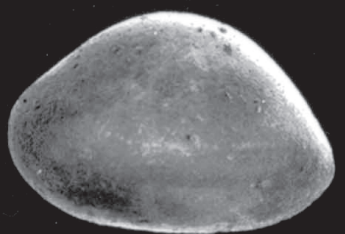

13

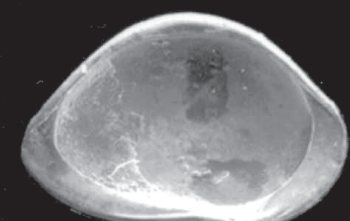

16
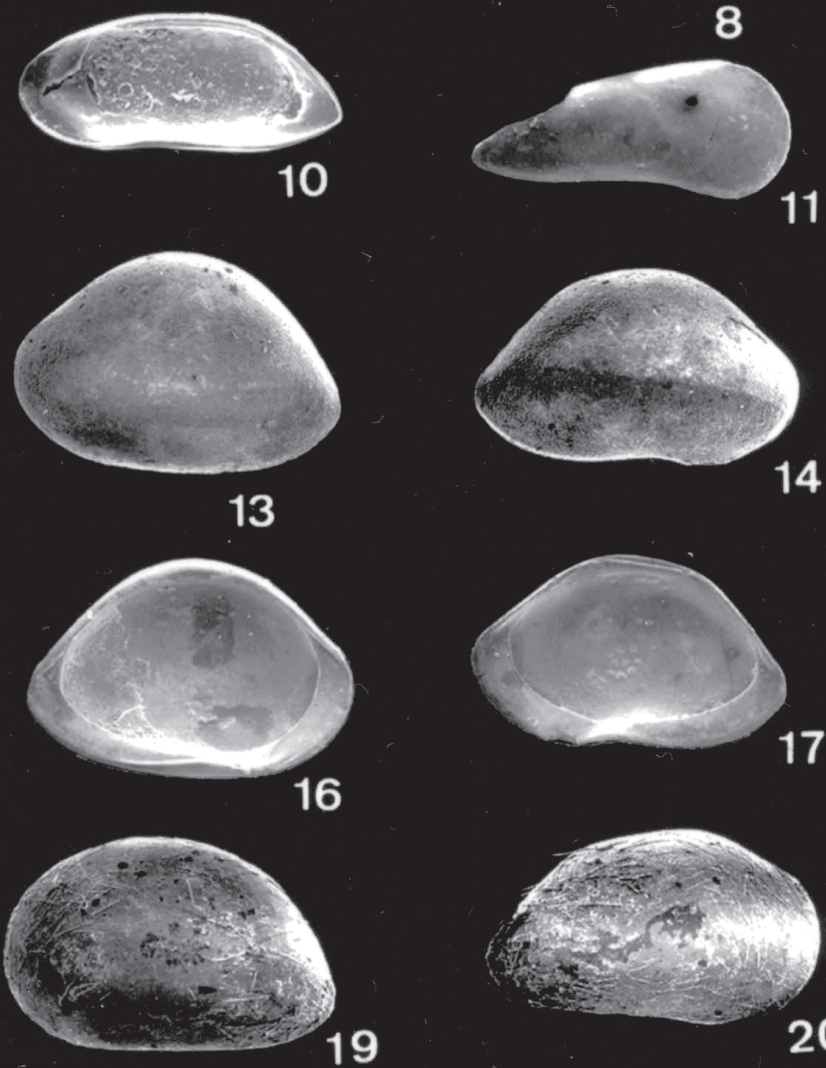
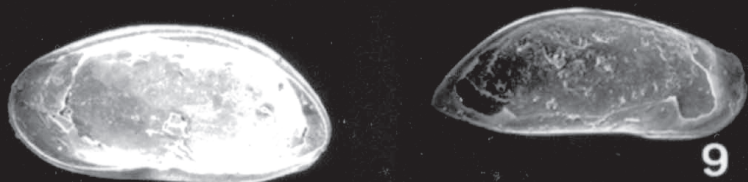

11

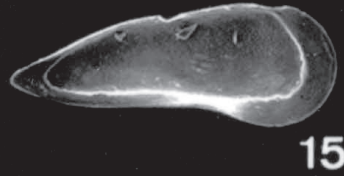

15

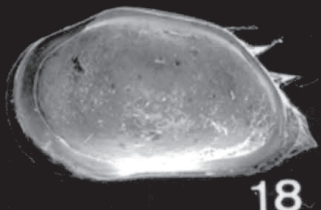

17

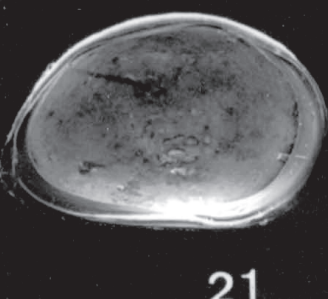

20

6

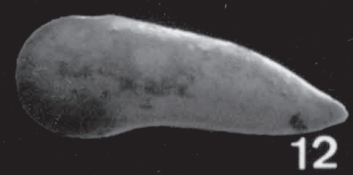

18

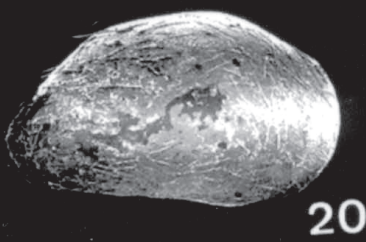

21

Figure 3. Sub-Recent pontocypridids and bairdiids from the southern Brazilian continental shelf. 1-2 Argilloecia parameridionalis: 1. Homotype, carapace, RV, external view, MP-O-1817, x 63,3; 2. Homotype, carapace, LV, external view, MP-O-1817, x 63,3. 3, 6, 9, 10 Argilloecia subacuta sp. nov.: 3. Holotype, carapace, RV, external view, MP-O-1819, x 70,4; 6. Holotype, carapace, LV, external view, MPO-1819, x 72; 9. Holotype, carapace, LV, internal view, MP-O-1819, x 74; 10. Holotype, carapace, RV, internal view, MP-O-1819, x 70,4 4, 5, 7, 8 Argilloecia inflata sp. nov.: 4. Holotype, carapace, LV, external view, MP-O-1822, x 63,8; 5. Holotype, carapace, RV, external view, MP-O-1822, x 70,4; 7. Holotype, carapace, LV, internal view, MP-O-1822, x 65,5; 8. Holotype, carapace, RV, internal view, MP-O1822, x 70,4. 11,12,15 Pontocypris? punctatus sp. nov.: 11. Holotype, carapace, RV, external view, MP-O-1824, x 54,3; 12. Holotype, carapace, LV, external view, MP-O-1824, x 52,7; 15. Paratype, carapace, LV, internal view, MP-O-1825, x 54. 13,14,16,17 Bairdoppilata sudbrasiliensis sp. nov.: 13. Holotype, carapace, LV, external view, MP-O-1828, x 32,5; 14. Holotype, carapace, RV, external view, MPO-1828, x 33; 16. Holotype, carapace, LV, internal view, MP-O-1828, x 32,5; 17. Holotype, carapace, RV, internal view, MP-O-1828, x 32,2. 18-21. Neonesidea? rotunda sp. nov.: 18. Holotype, carapace, RV, internal view, MP-O-1834, x 34,9; 19. Holotype, carapace, LV, external view, MP-O-1834, x 36,8; 20. Holotype, carapace, RV, external view, MP-O-1834, x 37,7; 21. Holotype, carapace, LV, internal view, MP-O-1834, x 36,8. 
Diagnosis. Typically bairdioid in lateral view. Almost perfectly fusiform in dorsal view, with greatest width medianly and equal attenuation towards each end margin. Thick-shelled. Carapace surface finely punctate.

Holotype. MP-O-1828, carapace.

Paratypes. MP-O-1829, carapace; MP-O-1830, carapace; MPO-1831, VE; MP-O-1832, juvenile carapace; MP-O-1833, VE. Material. 123 adult valves, 21 carapaces and 336 juveniles. Type locality and horizon. Southern Brazilian continental shelf, sample Leg 2-3194 (2451'S, 45¹4`W, depth 104 m). Recent. Description. Typically bairdioid in lateral view, with the usual different shape and outline of the two valves. Almost perfectly fusiform in dorsal view, with greatest width medianly and equal attenuation towards each end margin. Not strongly inflated laterally. Greatest height antero-medianly in RV; medianly in LV. Surface finely punctate. Internal features as for genus. Central muscle scars with a circle of seven rounded scars and one central adductor scar. There is a vertically disposed anterior scar, a number of dorsal scars and an elongate antero-ventral mandibular scar.

Dimensions (mm). Holotype MP-O-1828: RV, length: 1.18; height: 0.70; LV, length: 1.20; height: 0.84. Paratype MP-O-1829: RV, length: 1.16; height: 0.68; LV, length: 0.16; height: 0.72 ; width: 0.44. Paratype MP-O-1830: RV, length: 1.10; height: 0.62; LV, length: 1.12; height: 0.78. Paratype MP-O-1831: VE, length: 1.06; height: 0.68. Paratype MP-O-1832: RV, juvenile, length: 0.94; height: 0.56; LV, length: 0.94; height: 0.62 .

Remarks. Bairdoppilata sudbrasiliensis sp. nov. is similar to Bairdia villosa Brady (1880) but is smaller, less elongate, more arched dorsally, has a less punctate surface and lacks the small mid antero-dorsal protuberance of the LV present in B. villosa. The present species is also similar to Bairdia simplex Brady (1880), but differs in being more dorsally arched, especially in the LV and has the postero-median area more angulate and the antero-ventral angle more prominent in the RV. Bairdia simplex is also more elongate and less high. The comparison of these species was facilitated by study of the lectotypes B.M. 81.5.13 and B.M. 80.38.44 of the Brady (1880) Collection, Natural History Museum, London.

Distribution. South Brazilian continental shelf between $31^{\circ} 48,3^{\prime}$ and $22^{\circ} 08^{\prime} \mathrm{S}$. Depth range from $27 \mathrm{~m}$ to $164 \mathrm{~m}$, in sandy biodetritic sediments.

\section{Genus Neonesidea Maddocks,1969 \\ Neonesidea? rotunda sp. nov.}

(Figure 3: 18-21)

Neonesidea sp. cf. N. australis Chapman. Whatley et al., 1998a:.92, pl.1: 12-15.

Neonesidea sp. Drozinski et al., 2003, tab. 2, figs. 4n-o.

Derivation of name. $\mathrm{L}$. With reference to the rounded to ovate carapace of this species.

Diagnosis. In lateral view, LV strongly subovate, RV more acuminate posteriorly. Strongly inflated laterally. Ornament a delicate open reticulation with concentric component dominant. Holotype. MP-O-1834, carapace.
Paratypes. MP-O-1835, carapace; MP-O-1836, VE; MP-O1837, juvenile carapace.

Material. 98 adult valves, 2 carapaces and 737 juveniles. Type locality and horizon. Southern Brazilian continen-

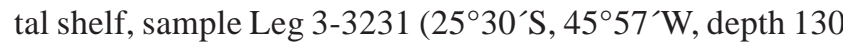
m). Recent.

Description. Carapace strongly inflated in dorsal view. In lateral view, LV strongly subovate, RV more acuminate posteriorly. Anterior margin broadly rounded in LV but with distinct antero-dorsal angle in RV, above which the anterodorsal slope is slightly concave. Posterior margin more attenuated in LV than RV, apex blunt, subdorsal. Posterodorsal slope slightly convex in LV, straight, slightly longer in $\mathrm{RV}$ and bearing three prominent spines. Dorsal margin straight and inclined towards the posterior in RV; gently convex in LV. Ventral margin slightly concave in the median area, more so in RV than LV. Ornament a delicate open reticulation with concentric components dominant. Internal characters as for genus. Central muscle scars comprise seven circular scars disposed about a central scar.

Dimensions (mm). Holotype MP-O-1834: RV, length: 1.06; height: 0.60; LV, length: 1.06; height: 0.68. Paratype MP-O1835: RV, length: 1.10; height: 0.64; LV length: 1.08; height: 0.70. Paratype MP-O-1836: LV, length: 1.08; height: 0.68 . Paratype MP-O-1837: RV, juvenile, length: 0.86; height: 0.52; LV, length: 0.86; height: 0.56 .

Remarks. The generic position of this species is in doubt. Its muscle scars are similar to Paranesidea Maddocks. However, the species lacks the denticles on the anterior and posterior margins and other characters of Paranesidea as defined by Maddocks (1969). This species is similar to Bairdia ovata Brady (1880) but differs in that the dorsal margin of the $\mathrm{RV}$ is less rounded. Neonesidea? rotunda sp. nov. is also similar to Bairdia australis Chapman, 1914. However, the present species is convex antero-dorsally and has a less accentuated postero-dorsal angle. The specimens recorded by Whatley et al. (1998a) from the southernmost Brazilian coast were all juvenile.

Distribution. Southern Brazilian continental shelf between $31^{\circ} 30.9^{\prime} \mathrm{S}$ and $31^{\circ} 32.2^{\prime} \mathrm{S}$, depth range from $22 \mathrm{~m}$ to $120 \mathrm{~m}$, on sandy sediments (Whatley et al.,1998a). In the present study it occurs between $32^{\circ} 57^{\prime} \mathrm{S}$ and $22^{\circ} 50^{\prime} \mathrm{S}$ in a depth range from $64 \mathrm{~m}$ to $158 \mathrm{~m}$, predominately on muddy sediments.

\section{CONCLUSIONS}

The study of the families Pontocyprididae and Bairdiidae from the southern Brazilian continental shelf resulted in the description of five new species: Argilloecia inflata, A. subacuta, Pontocypris? punctatus, Bairdoppilata sudbrasiliensis and Neonesidea? rotunda, and in the register of Argilloecia parameridionalis Whatley et al., 1998a. The generic position of Pontocypris? punctatus sp. nov. and Neonesidea? rotunda sp. nov. remains doubtful due to the problematic diagnostic character of these genera. The zoogeographical distribution of the studied species characterized them as endemic to the south Brazil, with 
exception of Argilloecia inflata and A. parameridionalis which also reach the Argentinean coast $\left(52^{\circ} \mathrm{S}\right)$.

\section{ACKNOWLEDGEMENTS}

The authors are grateful to CECO (Centro de Estudos Costeiros e Oceanográficos) at Universidade Federal do Rio Grande do Sul for the provision of samples. Thanks to John E. Whittaker from the Natural History Museum, London, for permission to access the Brady Collection; to David Griffiths and Geraint Hughes, from the University of Wales, Aberystwyth, for the photographic works. The authors thanks to the referees for critical reading and suggestions. M.I.F.R. and J.C.C. gratefully acknowledges the CNPq by the financial support (grants 520309/99-5 and 475313/03-8).

\section{REFERENCES}

Aiello, G.; Coimbra, J.C. \& Barra, D. in press. Ruggiericythere, a new shallow water marine ostracode genus from Brazil. Bolletino della Società Paleontologica Italiana.

Boltovskoy, E. 1970. Distribution of the marine littoral Foraminifera in Argentina,Uruguay and Southern Brazil. Marine Biology, 6(4):335-344.

Boltovskoy, E. 1976. Distribution of Recent Foraminifera of the South American Region. Foraminifera, 2:171-236.

Boltovskoy, E. 1979. Paleoceanografia del Atlántico Sudoccidental desde el Mioceno, según estudios foraminiferológicos. Ameghiniana, 16:3-4.

Boltovskoy, E. 1981. Massas de água en el Atlántico Sudoccidental. In: D. Boltovskoy (ed.) Atlas del zooplancton del Atlántico Sudoccidental y métodos de trabajo con el zooplancton marino. Mar del Plata, Publicación Especial (UNIDEP), p.227-237.

Bonaduce, G.; Ciampo, G. \& Masoli, M. 1975. Distribution of Ostracoda in the Adriatic Sea. Pubblicazioni della Stazione Zoologica di Napoli, suppl. 40:1-304.

Brady, G.S. 1866. On new or imperfectly known species of marine Ostracoda. Transactions of the Zoological Society of London, 5:359-393.

Brady, G.S. 1880. Report on the Ostracoda dredged by the H.M.S. Challenger during the years 1873-1876. Report on the scientific results of the voyage of H.M.S. Challenger, Zoology, 1(3):1-184.

Carmo, D.A. \& Sanguinetti, Y.T. 1995. Krithe occurrence on the Brazilian continental margin - an ecological approach. In: J. Ríha (ed.) Ostracoda and Biostratigraphy. Rotterdam, Balkema, p.407-412.

Carmo, D.A. \& Sanguinetti, Y.T. 1999. Taxonomy and palaeoceanographical significance of the genus Krithe (Ostracoda) in the Brazilian margin. Journal of Micropaleontology, 18:111-123.

Chapman, F. 1914. Description of new and rare fossils obtained by boring in the Mallee. Proceedings of the Royal Society of Victoria, 27(5):28-71.

Chaves, A.F. 1983. Processos e Métodos - Introdução Geral. In: Reconhecimento Global da Margem Continental Brasileira, Rio de Janeiro, CENPES/DINTEP, p.7-32. (Série Projeto REMAC 6).

Coimbra, J.C. \& Bergue, C.T. 2001. Ostracodes quaternários do talude da bacia de Santos, Brasil. In: CONGRESSO DO QUATERNÁRIO DE PAÍSES DE LÍNGUAS IBÉRICAS, 1, 2001. Acta, Lisboa, Universidade de Lisboa, p. 105-108.
Coimbra, J.C. \& Bergue, C.T. 2003. A new Recent marine Ostracoda species (Hemicytheridae) from Brazil. Iheringia, série Zoologia, 93(3): 243-247.

Coimbra, J.C.; Carreño, A.L. \& Ferron, F. A. 1994 . Holocene Podocopida Ostracoda from Sepetiba Bay, Brazil: some dominant taxa. Pesquisas, 21(2):90-99.

Coimbra, J.C. \& Ornellas, L.P. 1987.The Subfamily Orionininae Puri, 1973 (Ostracoda; Hemicytheridae) in the Brazilian Continental Shelf. Part II. Systematic of the genus Caudites Coryell \& Fields, 1937. Pesquisas, 19(2):55-79.

Coimbra, J.C. \& Ornellas, L.P, 1989, Distribution and ecology of sub-Recent Orionininae (Ostracoda) in the Brazilian continental shelf. Revista Brasileira de Geociências, 19(2):177-186.

Coimbra, J.C.; Sanguinetti, Y.T. \& Bittencourt-Calcagno, V.M. 1995. Taxonomy and distribution patterns of Recent species of Callistocythere Ruggieri, 1953 (Ostracoda) from the Brazilian continental shelf. Revista Española de Micropaleontología, 27(3):117-136.

Drozinski, N.G.; Coimbra, J.C.; Carreño, A.L. \& Bergue, C.T. 2003. Ostracoda cool water masses indicators from the Rio Grande do Sul State, Brazil - a first approach. Revista Brasileira de Paleontologia, 5:59-71.

Godoi, S.S. de. 1982. Estudo das variações sazonais da frente oceânica subtropical entre a Corrente do Brasil e a Corrente das Malvinas, utilizando dados oceanográficos e do Satélite $\mathrm{SmS}$-2. Programa de Pós-graduação em Sensoriamento Remoto, INPE. Dissertação de Mestrado, 328 p.

Hartmann, G. 1955. Neue marine ostracoden der Familie Cypridae und der Subfamilie Cytherideinae der Familie Cytheridae aus Brazilian. Sonderdruck Zoologischen Anzeiger, 154(5/6):109-127.

Hartmann, G. 1956. Weitere neue marine Ostracoden aus Brasilien. In: E. Titchak \& K.H.W. Koepeke (eds.) Beiträge zur neotropischen Fauna. Jena,Gustav Fischer Verlag, p.19-62.

Koswmann, R.O. \& Costa, M.P.A. 1979. Sedimentação quaternária da margem continental brasileira e área adjacentes. In: Projeto REMAC - Reconhecimento Global da Margem Continental Brasileira, Rio de Janeiro, CENPES/DINTEP, p.1-55. (Série Projeto REMAC 8).

Machado, C.P. \& Drozinski, N.G. 2002. Taxonomia e distribuição de Actinocythereis brasiliensis sp. nov. (Podocopida, Trachyleberididae) na plataforma continental brasileira. Iheringia, série Zoologia., 92(3):5-12.

Maddocks, R.F. 1969. Revision of Recent Bairdiidae (Ostracoda). U. S. National Museum Bulletin, 295:1-126.

Martins, I.R. 1984. Aspectos da oceanografia física do Atlântico Sul. Pesquisas, 6:76-90.

Purper, I. \& Ornellas, L.P. 1989. New species of Paracytheridea (Ostracoda) in the Brazilian continental shelf. In: CONGRESSO BRASILEIRO DE PALEONTOLOGIA,11, 1989. Anais, Curitiba, UFPR, p.721-732.

Ramos, M.I.F. 1994. The ostracod genus Coquimba Ohmert, 1968 from the Brazilian continental shelf. Revista Española de Micropaleontología, 26(3):65-82.

Ramos, M.I.F. 1996. Taxonomy and zoogeography of the ostracod genera Nanocoquimba and Cornucoquimba Ohmert, 1968 from Recent sediments on the Brazilian continental shelf. Revista Española de Micropaleontología, 28(1):105-128.

Ramos, M.I.F. 1998. Taxonomia e zoogeografia dos ostracodes marinhos recentes da plataforma continental sul-brasileira, entre Cabo Frio e Chuí. Programa de Pós-graduação em Geociências, Universidade Federal do Rio Grande do Sul, Tese de Doutorado, 258 p. 
Ramos, M.I.F.; Coimbra, J.C.; Whatley, R.C. \& Moguilevsky, A. 1999. Taxonomy and ecology of the Family Cytheruridae (Ostracoda) in Recent sediments from the northern Rio de Janeiro coast, Brazil. Journal of Micropalaeontology, 18(1):116.

Weber, R.R. 1994. Diagnóstico ambiental oceânico e costeiro das regiões sul e sudeste do Brasil. Oceanografia Química, 3:254-263.

Whatley, R.C. \& Coles, G.1987. The Late Miocene to Quaternary Ostracoda of Leg 94, Deep Sea Drilling Project. Revista Española de Micropaleontología, 19:33-97.

Whatley, R.C.; Moguilevsky, A.; Chadwick, J.; Toy, N. \& Ramos, M.I.F. 1998 a. Ostracoda from the South West Atlantic. Part
III. The Argentinian, Uruguayan and southern Brazilian continental shelf. Revista Española de Micropaleontología, 30(2):87-116.

Whatley, R.C.; Ramos, M.I.F.; Moguilevsky, A. \& Chadwick, J. 1998 b. The provincial distribution of benthonic Recent littoral and shelf Ostracoda in the SW Atlantic. Bulletin des Centres de Recherches Exploration Production Elf Aquitaine, 20:83-96.

Wood, A.M., Ramos, M.I.F. \& Whatley, R.C. 1999. The palaeozoogeography of Oligocene to Recent Ostracoda from Neotropics to Antarctica. Marine Micropaleontology, 37:345-364.

Received January, 2004; accepted April, 2004. 